\title{
US Interest in Afghanistan and Current Peace Prospects
}

* Dr. Muhammad Tariq, Lecturer (Corresponding Author)

** Saira Bano, Lecturer

*** Muhammad Amir, Lecturer

\begin{abstract}
The long-standing presence of the United States in Afghanistan is coming to an end by April 2021 as a result of the February 29, 2020 US-Taliban Agreement. It was the 9/11 syndrome that increased the interest of the US and its allied partners in Afghanistan. The main objectives of the study include the US interest in Afghanistan, maintenance of security inside Afghanistan by the United States and its allied partners, and the current prospects of peace settlement in Afghanistan. The drawdown of the US forces from Afghanistan started in 2014 and complete withdrawal is going to take place by April 2021 whereby responsibility of the security of Afghanistan would completely shift to the Afghan National Defense and Security Forces and the role of the US troops catering to training, assisting and supporting the ANDSF would diminish.
\end{abstract}

Keywords: Afghanistan, US, Interest, Withdrawal, Peace and Security

Introduction

In September 2001, the foreign policy of the United States underwent an abrupt change when Afghanistan was raised from the lowest ebb of Washington to the highest post of foreign policy. In the same month, US troops were deployed to dethrone the government of the Taliban for having been involved in the attacks on Pentagon. By the end of December 2001, an interim government was installed in Afghanistan, to rebuild the institutions and infrastructure of the country (Ayotte, Dunford \& Lindborg, 2021). It was in 2004 that the new constitution was adopted in the country where the country's first democratic presidential elections were held in 2004 with the placement of President Hamid Karzai on the throne of Kabul. Peace and security could last for about five years in Afghanistan when the dawn of 2006 saw the re-emergence of the Taliban as an insurgent group putting a challenge to the authority and writ of the Afghan government and US security forces in the country. Resultantly the US implemented a military and civilian surge in Afghanistan in the years 2009 and 2010.

As a consequence of the military operations and getting their objectives realized, the US embarked upon the policy of drawdown of forces from Afghanistan in December 2014 and decided to withdraw all forces in a couple of years but this has yet to be given practical shape as the US forces are still there in Afghanistan under the nomenclature of Resolute Support Mission (RSM). Though the US and NATO-led military operations ended in 2014 yet the Afghan security forces needed a residual of 10,000 US troops and several thousand more from the NATO partners (NEWS, 2021). The main purpose of this force was to train, advice, and provide assistance to the Afghan security forces (Ayotte, Dunford, \& Lindborg, 2021). Since December 2014, the US forces have been there in Afghanistan under the patronage of the RSM when it was finally decided in February 2020 that all the US forces would completely withdraw from there by April 2021.

Main objectives of the study focus on:

i) US interest in Afghanistan

ii) Maintain security in Afghanistan

iii) Stability of the State

iv) Peace settlement in Afghanistan

Following the US-Taliban Talks in February 2020, meant for binging peace to Afghanistan between the US and Taliban, followed by the intra-Afghan talks, the United States had to reduce its troops to about 4,500 which created a sense of jubilation and prosperity among the Taliban and local

* Department of Political Science, Hazara University Mansehra Email: muhammadtariq@ hu.edu.pk

** Department of Pakistan Studies, Hazara University Mansehra

*** Department of Pakistan Studies, Abbottabad University of Science \& Technology, Abbottabad 
inhabitants of Afghanistan. In continuation of the peace parleys, the Trump administration on January 15, 2021, announced to further reduce the US forces in Afghanistan to 2,500, which again created further jubilation among the various circles and particularly the Taliban that has become one of the major stakeholders in the Afghan government. It is important to know that this reduction in the strength of the US forces in Afghanistan is much greater than what was required by the Doha Agreement of February 2020 emphasizing the drawdown of the foreign troops from Afghanistan (GIESSMANN, 2020). This move by the US administration has been highly applauded by the Taliban and other local groups since they would feel free to have a government of their choice and maintain security measures in the country as per their own sweet will.

\section{US Interest in Afghanistan}

Since September 2001 the US has been maintaining law and order in Afghanistan having brought in a constitution and established a presidential democratic set up there in 2004. The democratic setup has provided for the provision of democratic values and norms and done away with the self-styled government by the then ruling party of Taliban. Now since the US has accomplished her task of rebuilding and reconstructing the infrastructure of the country, decided in December 2014 to reduce her forces in Afghanistan which is going to wind up her military operations by April 2021. Some of the key factors that led to the interest of the US are:

a) Prevent Al-Qaeda and other terrorist groups from attacking the United States and allied partners in the future. This is one of the key factors leading towards the direct involvement of the United States in the affairs of Afghanistan because the Al-Qaeda had directly challenged the writ of the United States and the allied partners by asserting their authority in the global politics. Currently, the US has been facing the threat inside Afghanistan from some of the extremist groups such as the Al-Qaeda, the Taliban, and the ISKP-the Islamic State of Khorasan Province. But this threat has now been overcome mostly by the US military operations and partly by the US-Taliban deal of February 2020. The United States in collaboration with the Afghan security forces has been pressing hard on curbing the terrorist groups from raising their heads and becoming a future threat to the government of Afghanistan and other global powers.

b) Prevent terrorists and other extremist groups from obtaining nuclear weapons and or materials to avoid instability in the region. Numerous smaller groups located in Afghanistan are focusing on the India-Pakistan rivalry poses a threat to the interest of both India and Pakistan resulting in the instability of the region (Tariq, India-Pak Rivalry in Afghanistan, 2015). There are still concerns regarding the possibility of nuclear weapons falling into the hands of terrorist groups (Ayotte, Dunford Jr., \& Lindborg, 2021) but it is extremely difficult to assess the possibility of this happening. Even if this possibility happens, then the consequences of such possession would be greatly detrimental for the regional stability as the non-state actors would have another strong weapon of access to the regional and global security. The most alarming fact in such a case would be the possibility of an attack on the US installations cannot be ruled out (Ayotte, Dunford Jr., \& Lindborg, 2021).

c) Maintenance of regional stability is also one of the key concerns of the United States at both the regional and global levels. The possibility of war between nuclear-armed states represents the greatest concern in the region. Of all the six neighbors of Afghanistan, three immediate neighbors (China, Iran, and Pakistan) possess nuclear weapons while the other two regional powers (Russia and India) are also in possession of nuclear weapons. An unstable Afghanistan may cause great damage to the regional security of the region in the wake of possession of nuclear weapons by the five neighboring countries of Afghanistan. SO, the stability of the entire region of South Asia rests upon the stability of Afghanistan where the non-state actors have been striving to pose threat to the security of the government.

d) Help in sustaining an Afghan state able to contain or overcome extremism, illegal narcotics, mass migration, and other potential threats that may lead towards the stability of Afghanistan and resultantly help in maintaining the security of the regional powers, particularly Pakistan which is the immediate neighbor of Pakistan and where the elements of extremism, cross border infiltration of insurgents, mass migration and illegal smuggling of narcotics may deteriorate the security of the region. An unstable Afghanistan may increase the possibility of Afghanistan backsliding to a haven for the terrorists financed by transnational criminality, 
particularly the finances from illegal narcotics. It would increase the possibility of regional instability sparkling larger conflicts. This could create a new refugee crisis resulting in the destabilization of Afghanistan directly affecting the neighboring countries, aggravate the current migration crisis, and undermine the US prestige and credibility across the globe.

e) Maintaining US influence in Afghanistan by focusing on the credibility of US foreign policy and preserving the integrity of the allied powers that had stood by the United States in fighting the war against terrorism. Preserving the integrity of the allied powers has been one of the cardinal principles of US foreign policy. The outcome of the US and NATO mission in Afghanistan will bear an impact on the willingness of the allied powers to provide assistance and support to the foreign policy of the US at both the regional and global levels.

f) The prospects of how the US mission winds up in Afghanistan will lead towards the establishment of the fact that to what extent has the US been able to ingrain an impact on the global leadership and its influence in the politics of the world (Ayotte, Dunford \& Lindborg, 2021). The US mainly remains concerned with retaining the confidence of the allied powers to get their support in most of the affairs of the world. Retaining confidence of the allied powers is not only to the security of the US national interest but also vital to the regional and global security at large.

US interest in Afghanistan is fraught with many considerations which is very fruitful for the security paradigm of the regional and global powers. The main concern of the US has been preventing the Al-Qaeda and other terrorist networks that may pose threat to the global power in the future. With this aim, the terrorist networks were dealt with an iron hand by conducting various military operations with the collaborations of the allied forces of NATO. Another important consideration was the concern of the regional security since five of the neighboring countries of Afghanistan (Tariq, 2019) (China, Iran, Pakistan, Russia, and China) have the great potential of possessing nuclear weapons. Any access to one of these states by the non-state actors may put the security of the entire region in jeopardy. During the military operations in the post $9 / 11$ syndrome and even now during the peace parleys with the Taliban, the role of Pakistan has been crucial to the interest of the region and the United States. It is again in the interest of Pakistan and then in the interest of the region that crossborder infiltration of the insurgents, illegal smuggling of narcotics, and mass migration may revert Afghanistan to a sanctuary of terrorists and insurgents (Tariq, 2020) ). The most significant aspect of the US operation coupled with the mission of the NATO in Afghanistan will impact the willingness of the allied powers to support the moves of the United States in the future in any part of the world. So, the credibility of the US foreign policy rests upon the willingness of the allied powers in case of any pre-emptive step by the US which is necessary for regional and global security.

\section{Maintenance of Security}

The current threat to the security of the United States arising out of the various terrorist groups based in Afghanistan has been overcome on account of the efforts jointly taken by the foreign troops and the US-trained and sponsored the Afghan National Defense and Security Forces (ANDSF) and the continued struggle by the US military presence (Ayotte, Dunford Jr., \& Lindborg, 2021). It is also important to mention that the US withdrawal without the peace agreement with the Afghan government and Taliban would help in rebuilding the capabilities of the insurgent groups and terrorist groups to reassert their authorities in challenging the writ of the regional and global actors. In the pre9/11 syndrome, the different terrorist networks have worked in close collaborations with one another intending to get their design realized. Some of the security measures adopted by the US for maintaining security in Afghanistan are:

a) Due to the efforts of the US security troops, linkages and associations between the various networks have been destroyed resulting in the gap among these networks. It was under this consideration that the US-Taliban Agreement followed by the intra-Afghan talks was initiated leading towards the withdrawal of the US forces from Afghanistan by April 2021 (Tariq, 2020). The Taliban have pledged not to cooperate with the Al-Qaeda and other terrorist groups threatening the security of the United States and her allied powers nor acting as a host for such activities nor help in recruiting, training, and fund-raising. Now huge gap exists between the Taliban and other groups and particularly the Taliban and the ISKP as the former looks upon the latter as an enemy and have been instrumental in fighting against each other. 
b) The Afghan National and Defense Security Forces are almost dependent upon the US funding for marinating security in Afghanistan. Even after the withdrawal of the US forces from Afghanistan, US support would remain essential for training, strategic and logistic purposes. The effectiveness of the ANDSF for keeping security at all important installations of the country is still dependent upon the US troops and her presence there. This dependence of the ANDSF on the US support will continue for years since close operational, air support and intelligence partnership exists between the security forces of both Afghanistan and the United States. The US spends about $\$ 4.8$ billion per year for meeting the security requirements of Afghanistan even if it has not participated in any combat operation inside Afghanistan.

c) A quick US withdrawal from Afghanistan would probably worsen the conflict, provoking a wider civil war. According to the security analysts and experts 4,500 foreign security personnel are required for training, advising, and assisting the Afghan security forces but the reduced ratio of the US troops in Afghanistan to 2,500 may prognosticate a lacunae in the security paradigm of Afghanistan. So, the presence of 4,500 US troops in Afghanistan has been considered as a requirement for security there but further reduction to 2,500 may not be a sign of good omen for the country in the wake of the presence of non-state actors in Afghanistan.

It is a great reality that the security paradigm of Afghanistan still largely depends upon the logistic and financial support of the US administration. Moreover, the US troops under the nomenclature of Resolute Support Mission have been engaged in providing training, assistance, and coordination in the protection of key installations of the country. The efficacy and effectiveness of the ANDSF owes its success to the presence of the US troops since they ensure their presence in the key security areas of the country. It is also a fact that the US administration allocates $\$ 4.8$ billion each year to the government of Afghanistan for meeting the security requirements of the country. But this financial assistance is going to be discontinued in the wake of the US withdrawal from Afghanistan. It is still uncertain whether the ANDSF would be able to maintain security in Afghanistan or would look towards the US government for the financial assistance and logistic support in safeguarding the country against the terrorists and insurgents since she has experienced the worst scenario in the postSoviet withdrawal.

\section{Stability of the State}

Afghanistan has been regarded as a "fragile state" due to its broken social contract, weak institutions, and the disputed legitimacy of its government (Ayotte, Dunford \& Lindborg, 2021). This has largely been because it has been a war-stricken country for a long period of years where no political party was able to hold its tight control over the affairs of the state. The result was the fragility of the state that could be ruled by any party, state, or non-state actors when it deemed fit to rule over the country. The state does not have many sources of revenue generation and mostly remains dependent on the donor and funding agencies for running the transaction of the state. In the wake of the persistence of conflict continuing for long, she would not be in a position to raise sufficient revenues for the sustenance and survival of the country. The country has lost its legitimacy on account of corruption, a weak governance system, the presence of warlords, and the government's inability to provide effective justice services, and failure to resolve disputes.

Despite the provision of funding by the donor agencies and the crippling corruption, the Afghan government and their international partners have not been able to build a strong government inside the country to cope with the challenges of insurgency and terrorism. The US administration was very determined and optimistic about creating a strong government in the war-stricken country of Afghanistan but she could not do succeed in establishing a strong government despite efforts of long 19 years (Tariq, 2020). Some of the areas that still lack coherence include the public finance management department, the health system, the ministry of education, and parts of the security system. These sectors lack success and coherence owing to the lack of funds and revenue generation on part of the Afghan government. The Afghan government mainly remains dependent on the United States for her assistance and funding facility on humanitarian grounds that has led to the development of a vital advocate for rights as well as an increasingly effective government with the mechanism of accountability (Ayotte, Dunford \& Lindborg, 2021).

Despite the long-standing presence of the United States and its allied partners, the state system in Afghanistan remains fragile and weak where the institutions and some key sectors of the 
government are not well developed and remain parasitic on the United States for the provision of funding and donning. These departments have not been able to meet the requirements of the transaction nor had they the potentiality to run their affairs independently on account of lack of basic facilities of life.

\section{The Afghan Peace Settlement}

The current Afghan Peace Settlement also known as the Doha Agreement owes its origin to the USTaliban Talks of February 29, 2020, dilating upon the withdrawal of the US forces from Afghanistan by April 2021 (Clayton, 2020). The agreement is very comprehensive in so far as the peace and security in Afghanistan is concerned. It places some restrictions on both the US and Taliban, the former to withdraw her troops from Afghanistan by April 2021 while the latter's commitment to the effect not to recruit, train, or function otherwise that could threaten the United States and her allied partners in the areas controlled by the Taliban. The Taliban also pledged not to assist other terrorist groups including the Al-Qaeda in challenging the authority of the US in the areas dominated by the Taliban. It was also decided in the agreement that the United States would decrease its forces from the strength of 15,000 to 8,600 and then by April 2021 to withdraw completely from there subject to the terms and conditions of the agreement being met (Clayton, 2020). As a part of the peace agreement, the Taliban has also committed not to attack the international forces, important Afghan cities, and some other key areas.

The Doha Agreement makes provision for the military to military channel was created between the US and the Taliban for monitoring the compliance of the peace settlement. Despite commitment by the Taliban to refrain from activities of violence and terrorism, the Taliban took recourse to conduct violence and numerous small-scale attacks against the Afghan law enforcement agencies to retain the morale of the Taliban fighter in case of the failure of the peace process in Afghanistan (Clayton, 2020). The military to military channel has proved unable to adjudicate effectively the alleged instances of violations due to the lack of objective information regarding who perpetrated the attacks. The Doha Agreement was followed by the Intra-Afghan talks concentrating upon the exchange of prisoners from both the Afghan government and the Taliban.

While the peace talks were delayed, the Biden administration began to review the US-Taliban agreement, agreed upon during the previous Trump administration (Mehrdad, 2021). It is also pertinent to mention that the Biden administration is yet to forge a clear policy towards the "forever war" in Afghanistan but even with the Biden administration the forthcoming US withdrawal remains the main concern. The February 2020 agreement requires the Taliban to cut ties with the terrorist groups and particularly the Al-Qaeda and refuses to harbor foreign fighters targeting the US and allied partners in Afghanistan. The Taliban has clearly stated not to harbor any foreign fighters and has declared to punish those fighters who facilitate the foreign fighters in Afghanistan (Naushad, 2021). Moreover, during recent months, many phone calls were exchanged between the US officials and the Afghan government officials (Mehrdad, 2021). Telephonic communications were exchanged between the US Secretary of Defense, LIyod Austin, and President Ashraf Ghani, so did Secretary of State Antony Blinken. Similarly, National Security Advisor, Jake Sullivan talked to his Afghan counterpart. In all of these telephonic calls, the US officials have emphasized that the US administration was going to review the US-Taliban agreement and has been committed to supporting the Afghan government (Mehrdad, 2021).

\section{Conclusion}

The United States is going to wind up its ongoing military operation that has been functional in Afghanistan for the last 19 years as a consequence of the February 2020 US-Taliban Agreement followed by the Intra-Afghan Talks. There are still apprehensions whether the military operation in Afghanistan is going to end up or foreign troops would still ensure their presence in the wake of change of policies as a result of change of US administration. The Trump administration made many unexpected announcements regarding the early withdrawal of the foreign troops from Afghanistan even though some of the close allies of the Trump administration were not happy over the hasty decision made by him. According to an estimate of the security experts and analysts, 4,500 foreign security personnel are required to provide training, advice, and assistance to the law enforcement agencies of Afghanistan but even then the number of foreign troops in Afghanistan at present stands at 2,500 which is less than the required ratio of maintaining security over the key security sectors of the country. Moreover, the Biden Administration is also reported to review the current US-Taliban 
Agreement in terms of the growing need for security measures required at the key sectors of Afghanistan. Any hasty decision regarding the withdrawal of the US forces may result in the security vacuum coupled with the leadership crisis. The state may denigrate into a state of chaos where episodes of civil war, terrorism, and insurgency may recur frequently. But it is very much clear that the US has achieved her interest in Afghanistan by dethroning the then self-styled government of Taliban and has been successful in creating a democratic presidential set up based on the doctrine of general elections. She has also shown satisfaction over the current security situation of the country by reposing confidence in the law enforcement agencies of Afghanistan. Now, the most important task before the government of Afghanistan is the process of peace settlement with the various stakeholders of the country to avoid any mishap in the future. This may convert the country into a peace-loving country with a democratic setup. A stable Afghanistan is very much necessary for regional and global security.

\section{References}

Ayotte, K. A., Dunford Jr., J. F., \& Lindborg, N. (2021). A Pathway for Peace in Afghanistan . . Afghanistan Study Group.

Clayton, T. (2020). Afghanistan: Background and U.S. Policy: In Brief. Congressional Research Service.

GIESSMANN, H. J. (2020, December 21). Latest Developments in the Afghan Peace Process: A Commentary. Retrieved from https://berghof-foundation.org/news/latest-developments-in-theafghan-peace-process-a-commentary

Mehrdad, E. (2021, February 26). Even as Peace Talks Resume, Killing Soars in Afghanistan. Retrieved from https://thediplomat.com/2021/02/even-as-peace-talks-resume-killing-soars-inafghanistan/

Naushad, M. (2021, March 1). Pakistan and the Afghan Peace Process. Retrieved from https://www.thenews.com.pk/print/762940-pakistan-and-the-afghan-peace-process

NEWS, B. (2021, February 22). Afghanistan's Ghani sees 'Window of Opportunity' for Peace Process. Future Planet Solution for a sustainable world. London, England. Retrieved from https://www.bbc.com/news/world-asia-56144795

Tariq, M. (2015). India-Pak Rivlary in Afghanistan . (R. Sultana, Ed.) Frontier Women University Journal of Social Sciences, 1(2), 15-23.

Tariq, M. (2019). Pakistan's Security Dilemma with Afghanistan and India. Global Political Review, $70-77$.

Tariq, M. (2020, October). Afghanistan: Conflicts in the way of Peace Process. Conflict Quarterly Studies, 4(33), 53-62.

Tariq, M. (2020). US-Afghan Talks: Myths and Realities. Global Political Review, V(1), 104-111.

Tariq, M. (n.d.). US Withdrawal from Afghanistan: Latest Development and Security Situation (2020). Sir Syed Journal of Education and Social Research, 3(2), 290-297. doi:http://doi.org/ 10.36902/sjesr-vol3-iss2-2020(290-297) 